\title{
Sísifos... una montaña en las espaldas, anhelos de una chispa dorada
}

\section{Artículo de investigación artística}

\section{Daniel Ospina Moreno}

Universidad de Antioquia, Colombia

danospinamor@gmail.com

Recibido: 20 de septiembre de 2018

Aprobado: 30 de octubre de 2018

Cómo citar este artículo: Ospina Moreno, Daniel (2019). Sísifos... una montaña en las espaldas, anhelos de una chispa dorada. Calle 14: revista de investigación en el campo del arte 14(25). pp. 34-57. DOI: https://doi. org/10.14483/21450706.14074 


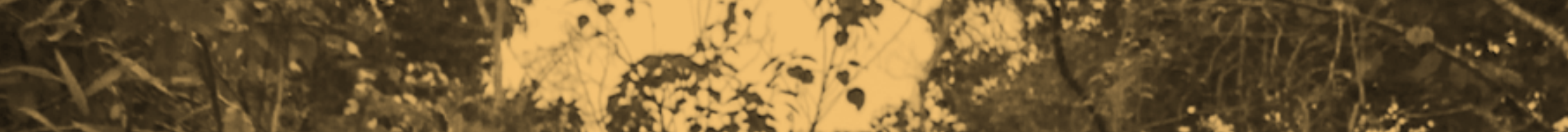
$17=$

se.

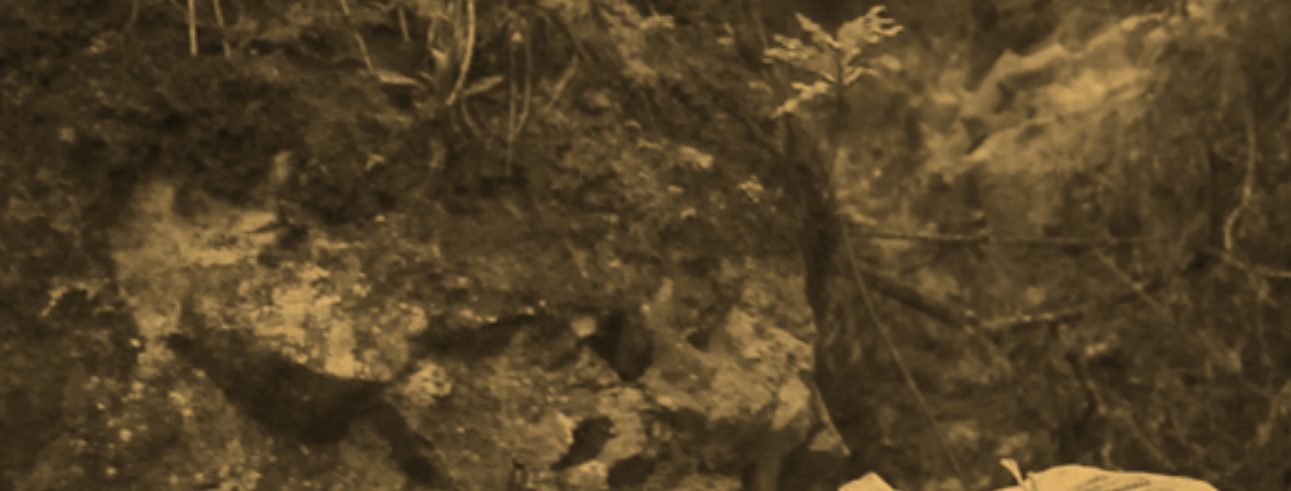
- $1-7$

$$
\text { 20. }
$$

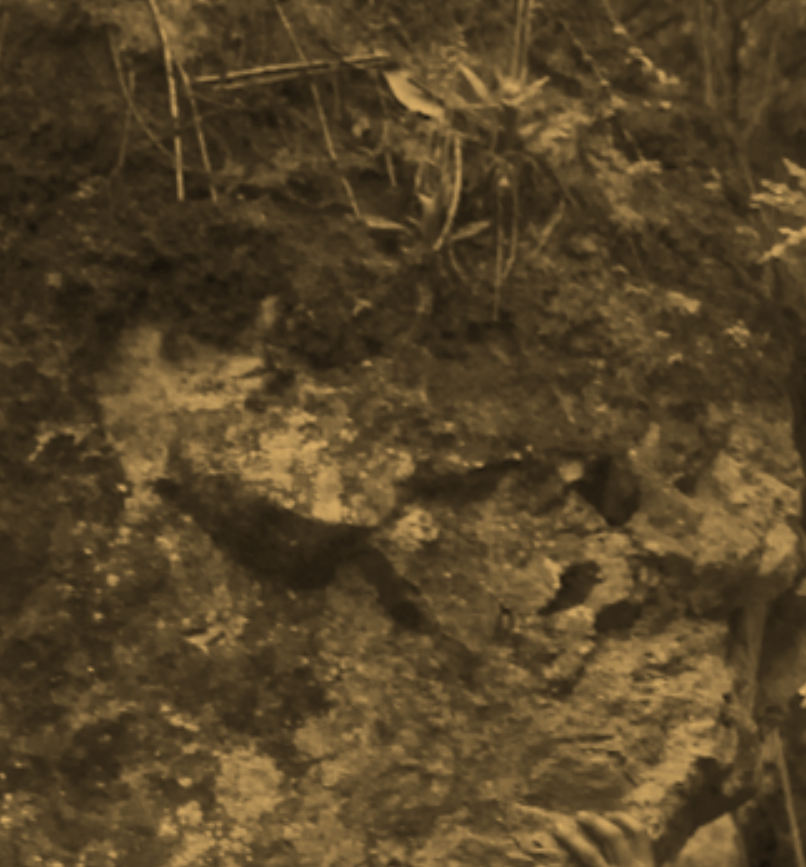$$
\text { 2. } 13 \text {. }
$$$$
\text { (1) }
$$

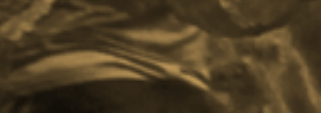
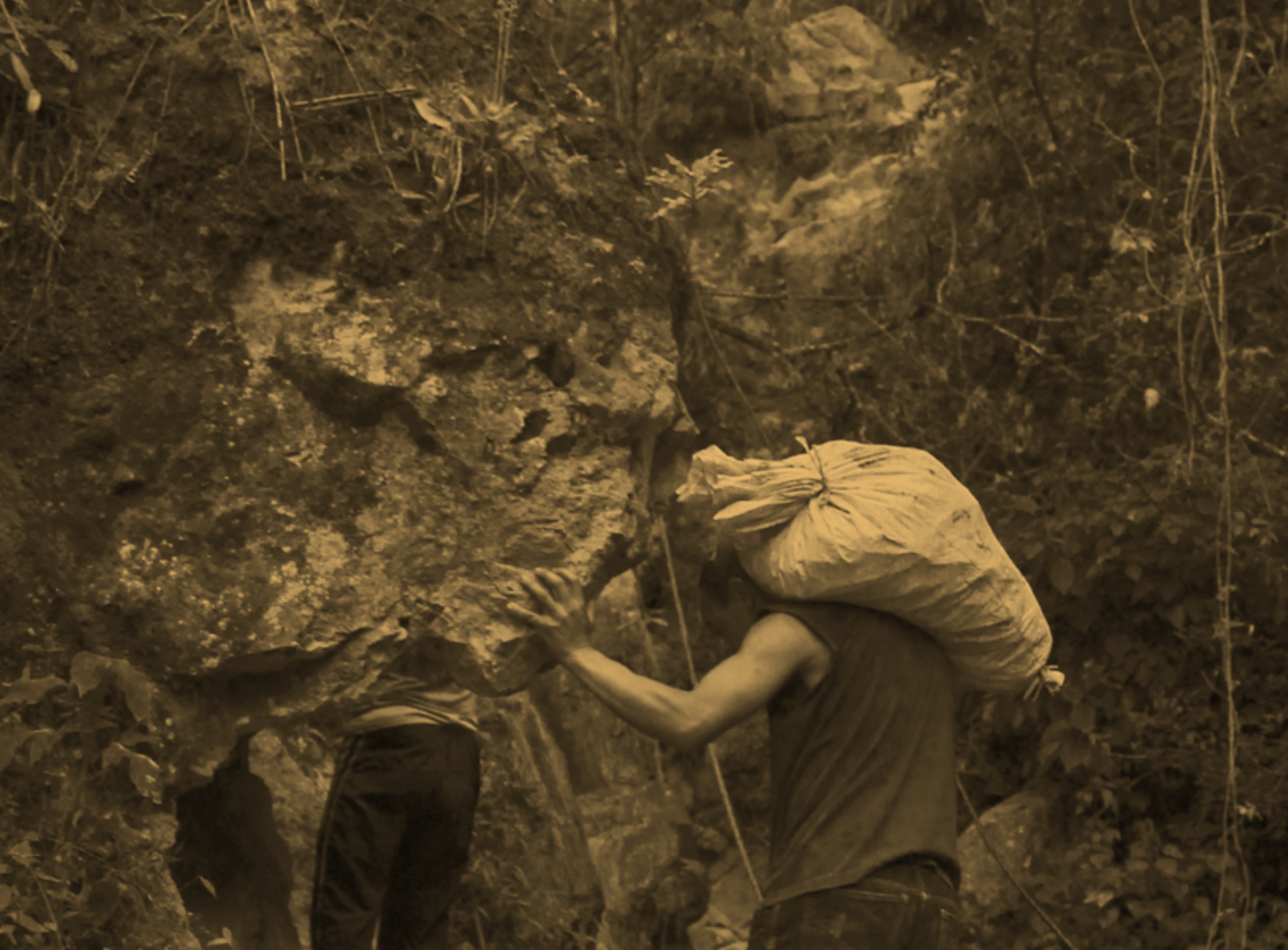

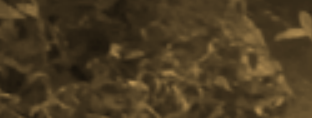

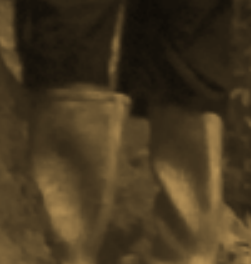

sis

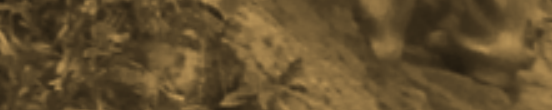

3
$y$
3

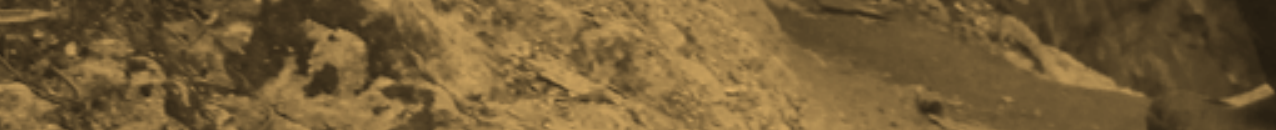
군

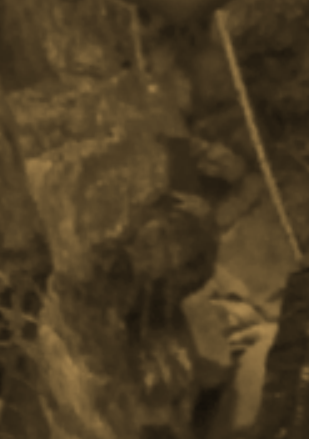

250
.
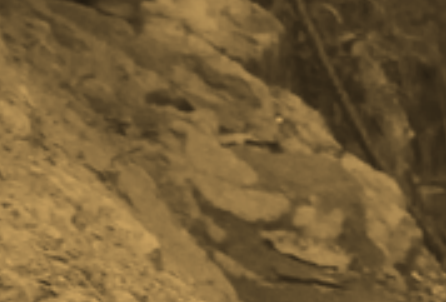

6os

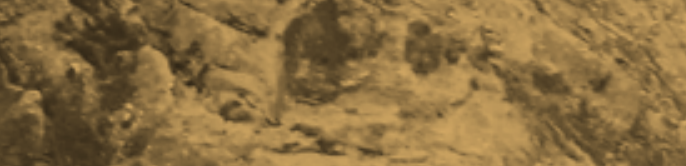
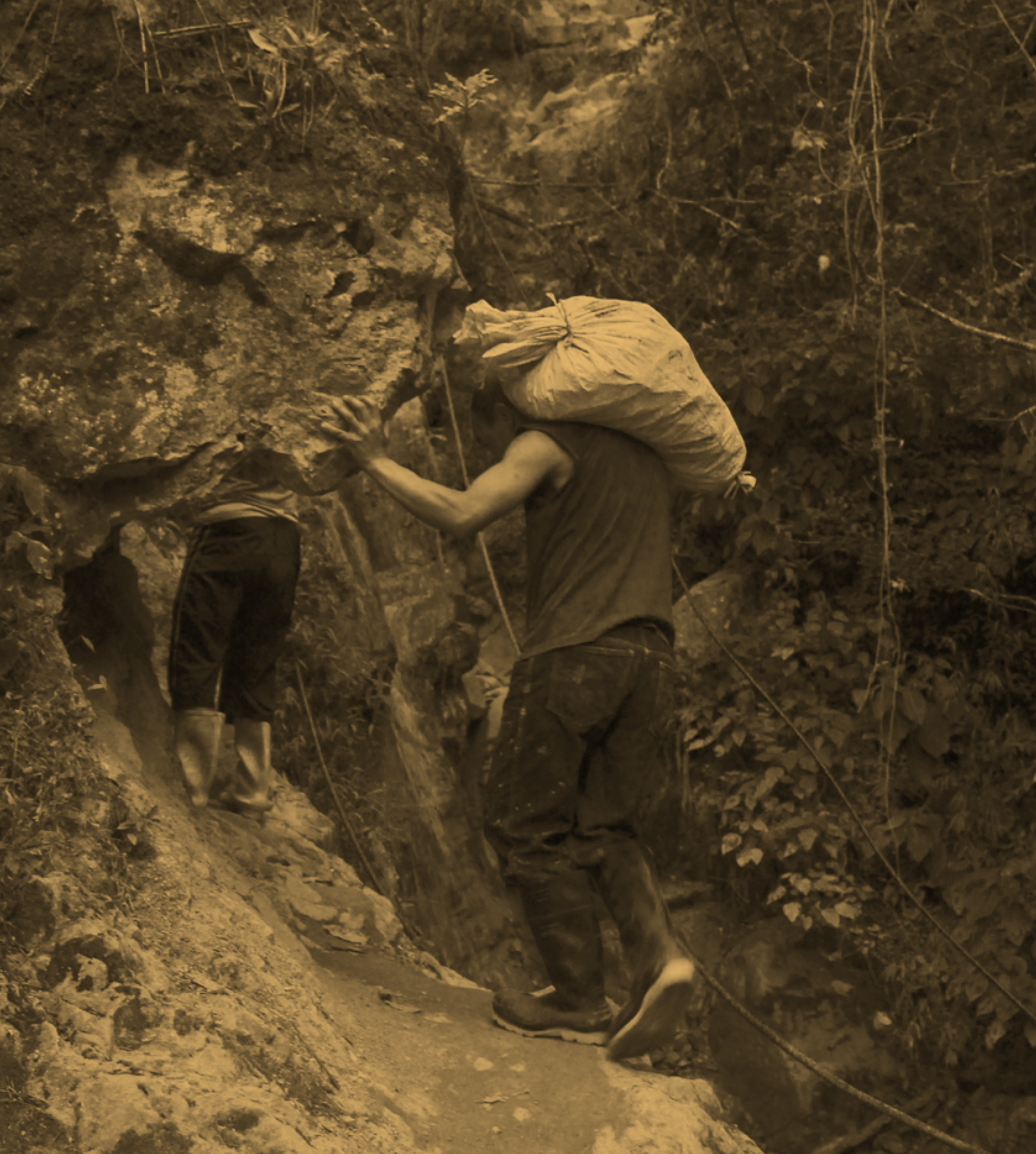


\title{
Resumen
}

Este relato visual se produce sobre una experiencia en la que busqué comprender desde adentro las dinámicas del extractivismo y sus impactos en la naturaleza y la sociedad, habitando por dos meses un contexto de extracción ilegal de oro. Esta vivencia se conecta con mi pregunta como artista que indaga por las expresiones y huellas del diálogo hombre-naturaleza en Colombia. Inquietud que me crea la necesidad de apropiar la geografía desde la vivencia. Así, también es clave aprender a leer desde los criterios de la ecología, la geología, la biología y la etnografía, procurando profundizar en leguajes para comprender esas complejas relaciones que modelan el paisaje. Me adentro en el contexto de Buriticá (Antioquia) en un momento de apogeo de la minería ilegal en el año 2016, con la intención de leer ese paisaje desde el punto de vista de quienes lo habitan y lo modelan.

\section{Palabras claves}

Buriticá; minería ilegal; paisaje; dialogo hombre-naturaleza; extractivismo

\begin{abstract}
This visual story is the product of an experience where I sought to understand from within the dynamics of extractivism and its impact on nature and society, inhabiting for two months a region where illegal gold mining takes place. This experience connected with my questions as an artist who investigates the expressions and traces of the dialogue between man and nature. This curiosity lead me to the need of appropriating geography from experience. Thus, it is also key to learn to read from the criteria of ecology, geology, biology and ethnography, trying to deepen into those languages to understand the complex relationships that shape the landscape. I enter the universe of Buriticá (Antioquia) in a moment of apogee of illegal mining in 2016, with the intention of reading that landscape from the point of view of those who inhabit and model it.
\end{abstract}

\section{Keywords}

Buriticá; illegal mining; landscape; man-nature dialogue; Extractivism

\section{Résumé}

Cette histoire visuelle est le produit d'une expérience dans laquelle j'ai cherché à comprendre la dynamique de l'extractivisme et son impact sur la nature et la société, vivant depuis deux mois dans une région d'extraction illégale d'or. Cette expérience rejoint mes questions en tant qu'artiste qui explore les expressions et les traces du dialogue entre l'homme et la nature. Cette curiosité m'amène à la nécessité de m'approprier la géographie à partir de l'expérience. Par conséquent, il est également essentiel d'apprendre à lire à partir des critères d'écologie, de géologie, de biologie et d'ethnographie, en essayant d'approfondir ces langues pour comprendre les relations complexes qui façonnent le paysage. J'entre dans l'univers de Buriticá (Antioquia) à un moment d'apogée de l'exploitation minière illégale en 2016, avec l'intention de lire ce paysage du point de vue de ceux qui l'habitent et le modélisent.

\section{Mots clés}

Buriticá; exploitation minière illégale; paysage; dialogue homme-nature; extractivisme 
Sísifo... uma montanha em suas costas, ansiando por uma faísca de ouro

\section{Resumo}

Essa história visual é o produto de uma experiência na qual busquei entender de dentro a dinâmica do extrativismo e seu impacto na natureza e na sociedade, habitando por dois meses uma região onde ocorre mineração ilegal de ouro. Essa experiência se conecta com minhas perguntas como artista que investiga as expressões e traços do diálogo entre homem e natureza. Essa curiosidade me leva à necessidade de me apropriar a geografia da experiência. Assim, também é fundamental aprender a ler os critérios de ecologia, geologia, biologia e etnografia, tentando aprofundar essas linguagens para entender as complexas relações que moldam a paisagem. Entro no universo de Buriticá (Antioquia) em um momento de apogeu da mineração ilegal em 2016, com a intenção de ler essa paisagem do ponto de vista daqueles que a habitam e a modelizam.

\section{Palavras-chaves}

Buriticá; mineração ilegal; paisagem; diálogo homem-natureza; extrativismo

\section{Maillallachiska}

Kai parlu kawachimi imasami iachachirka, sus maskaipi intindingapa. Kai iachaikuikuna imasami surkurkakuna kai mama alpakunamanda, i kausaikakuna iapa kuri tiaskapi. Kai kaugsaikuna kawarimi imasami nukakin purakuna kai alpa kulumbia suti ka. Imasami kai Nukapa tsabajukanapai nukakinb tapurini kai alpapi imasami kaugsai iukarii. Chasaitatmi chaia lingapa kai Nukanchipa sachukukuna i chasaiatapa nukanchipura maipimi kaugsanchi, chasami Nukanchipa rimai imasami iukanchi rimangu lukui punchakuna chasami iachaikungakuna imasan ka chi kaugsaikuna kai alpapi. Chi alpapi chi alpapi suti Buritika (A ntiokiapi) chipi chaiarkasi iapa kuni luar tiaskapi kasa watapi isakai waranga chunga sugta kaura, chipi kaskas; imasami kikin kawadurkarka i imasami kaugsai i kawakuna.

\section{Rimangapa Ministidukuna}

Buritika: alpa dueñog; putsiru suma kaska; giltiwa karlanakui; sachuku surkuikuna 
Buriticá, como se llamó el cacique que un día hace más de cuatrocientos años gobernó esta montaña ubicada en la cordillera occidental de lo que actualmente es Antioquia, difícil geografía quebrada por múltiples fallas geológicas, entre ellas se acentúa "La Cañada"; quebrada que en un tiempo fue pura, caudalosa y preciosa, tanto que la superficie de sus rocas, esas que se erosionaron para encausar estas aguas, dejaban ver hilos dorados entre las bandas de cuarzo que se suelen apreciar como simples líneas blancas que se ramifican en los peñascos; aquí fue o es tan abundante el sol hecho metal, que algunos segovianos relatan con exaltación como pudieron presenciar el metal en la superficie de los afloramientos rocosos en esta "montaña de oro" como se traduciría en las lengua de los pueblos exterminados por la colonización en la zona y que al parecer hicieron parte de la familia Katío. Buriticá un territorio y el nombre de un aguerrido ancestro gobernante que se resistió a entregar su territorio y su oro a los colonizadores que venían apoderándose de las montañas mientras huían de la selva húmeda tropical. Calcinado en la hoguera fue Buriticá un pasado ancestral del que solo sobrevive el nombre masacrado e incinerado junto con otros pobladores y asentamientos ancestrales en la región de occidente como ahora se conoce esta parte del departamento de Antioquia.

Se funda este asentamiento colono en 1614, saqueado el oro labrado con símbolos sagrados por sus primigenios habitantes, luego de robar todo lo que encontraron, se iniciaron operaciones mineras desde allí a lo largo del Cauca, donde son significativos como referente histórico Marmáto y Segovia, entre otros del país. Aquí en Buriticá no pervivió la práctica minera, que fue remplazada por nuevos pobladores de vocación campesina, agraria y como ingreso ocasional practicaron el trabajo minero ancestral, por lo que a esta tierra en un momento se le distinguía como remanso de paz... Pero el oro sigue allí, indígenas y españoles apenas si lo rasguñaron, y hace más de 20 años Continental Gold, explora y para el 2020 iniciará la operación extractiva a gran escala de 3.7 millones de onzas de oro y 10.7 millones de onzas de plata. Los segovianos afirman que la empresa explota desde el inicio de la exploración y en mi estancia al menos dos veces por semana aterrizaba un helicóptero en la mina ¿por qué o a qué iba?

Esto es Buriticá, un pueblo donde no pasaba nada, donde no llegaba nadie, también por lo paupérrimo de las políticas educativas y agrarias en la ruralidad antioqueña y colombiana, los jóvenes solían migrar pues "no había oportunidad de progresar ni nada... solo jornalear" según dicen algunos sujetos oriundos de allí, con los que tuve la posibilidad de interactuar en las minas y en el pueblo; cuando llega Continental Gold oficialmente en 2007, luego de múltiples hostigamientos de las guerrillas que dejaron silenciosa la exploración y aún más oscuros los socavones desde la década del 90.

Este territorio pasó de ser un remanso de paz a una geografía dantesca, una cofradía de los excesos, vida sostenida en la muerte; entorno de ambición materialista, drogas, alcohol, lenocinio, fortunas efímeras, y constante miseria del día después, llena de anhelos que devuelven el aliento, para continuar mañanas y noches dentro del Socavón "donde no se sabe cuándo se nos viene encima o si podremos salir, pero seguimos entrando" en búsqueda de la "Góngora" que deja atrás toneladas y toneladas de roca y lodo colmado de trazas de mercurio y explosivos que llegaron con la gente flotante y rebosante de expectativas por las entrañas de esta montaña donde confluyeron personas de Latinoamérica, el país y especialmente del Nordeste y Bajo Cauca Antioqueño, para el 2014 se podría decir que estos triplicaron los buritiqueños y en el 2016 a pesar del Estado y sus fuerzas militares que intentaban expulsar los mineros ilegales, estos seguían duplicando los locales.

Esta narrativa visual pretende acercar al lector a la metáfora de ese Sísifo, que puede ser cada de uno de estos seres que se dedican a hurgar las entrañas de la tierra y cargarlas en sus espaldas, en especial los segovianos con quienes conviví, trabajé y dialogué, en igualdad de condiciones como se dice coloquialmente, llegué con una mano atrás y otra adelante "al rebusque", como llegan todos allí, procuré vivir a su modo para comprender su contexto, a partir de conocer de cero todas sus labores y comprenderlas ejecutándolas, dedicarme a ellas y asumir el mercurio, entre otros elementos de este ambiente, en relación con mi cuerpo, a cambio del privilegio experiencial de compartir y ser pupilo de esta gente durante dos meses, ganándome su confianza, su amistad y la posibilidad de tomar fotografías que narran un poco de su entorno y sus prácticas.

En la modalidad de extracción de oro de beta, se mezclan algunas técnicas modernas como los taladros eléctricos y neumáticos, la dinamita, el anfo, el mercurio, el cianuro, los molinos, mecánicos que se alimentan y tienen su razón de ser en el material que sale a la superficie por medio de la práctica ancestral de la "catanga", sacar los costales llenos de rocas sujetado en la espalda, las "recuas de mulas" que cargan la 


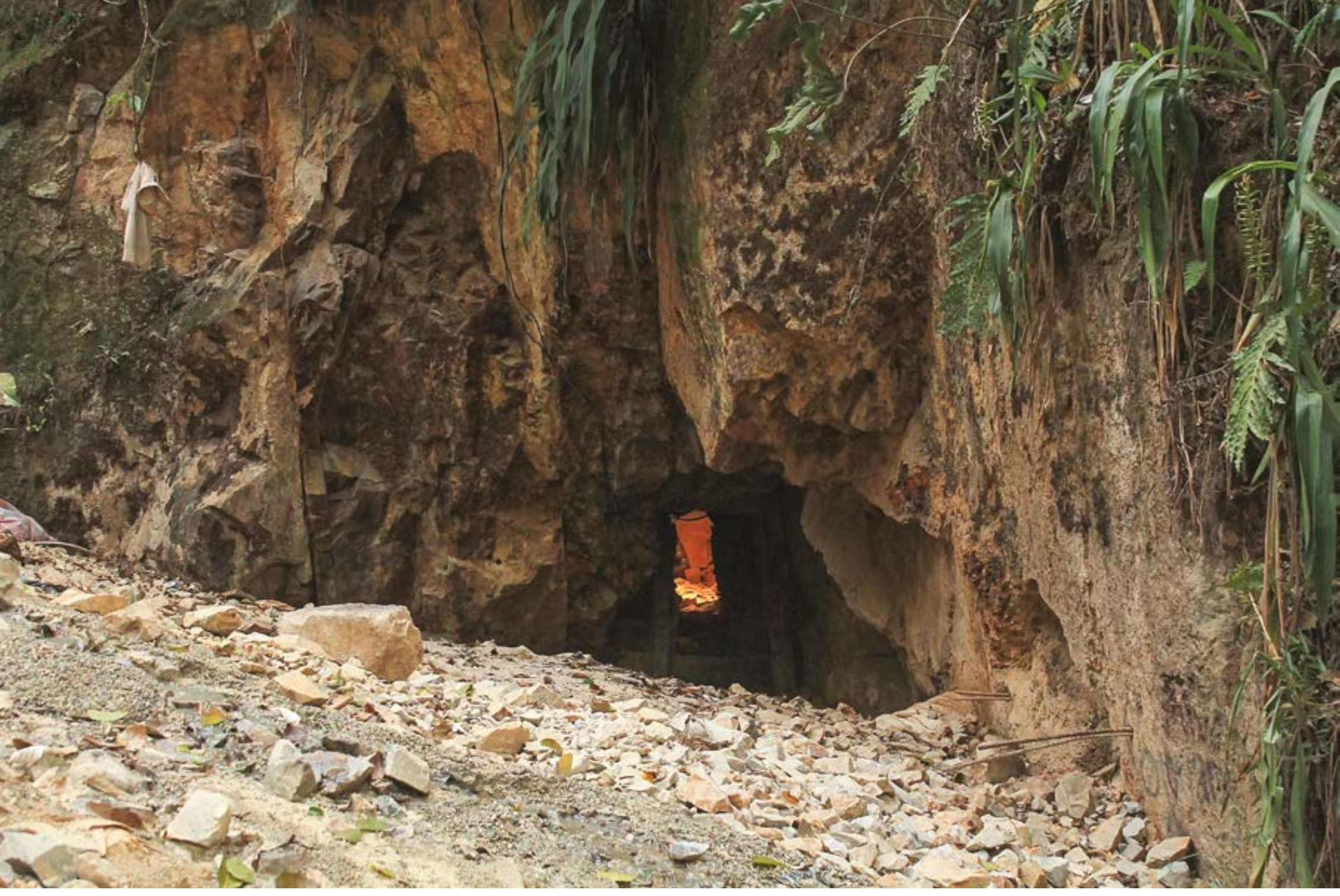

Imagen 2. Socavón... Daniel Ospina Moreno (2016). 
"mina" desde la superficie del socavón hasta el lugar de beneficio la "machadora" donde la piedra se vuelve gravilla, para terminar de molerse en "los cocos" o "entable" las rocas se vuelven un finísimo lodo, para luego hacer correr y correr agua que se hace turbia mientras purifica este lodo, "deslodando la mina" hasta llegar a las más pesada arenilla, que se menea una y otra vez con la batea quitando el sedimento hasta quedar solo una gran gota de mercurio, que se escurre en un trapo donde queda atrapado el oro pulverizado compacto en una masa gris mitad de mercurio. Se concluye con el recorte, que es la parte final de ese extenuante proceso que implica la búsqueda del oro, que se consigue "azogado" y se expone al fuego para regalarle el mercurio al aire y dejar solo el oro, un trozo que apenas cabe en la mano luego de costales cargados de rocas, mucha energía y mucha agua.

Apreciamos la expectativa del cateo a un frente que se inicia en la mina "La Roca" la esperanza de 10 mineros en un bulto de arena.

Paradójicamente donde yace y se explota el oro por ningún lado se ve dorado...

Esta búsqueda del metal, implica en su camino una trasformación total del paisaje y sus ritmos sociales, naturales y agrarios, toneladas de roca por gramos de metal, una proporción que se evidencia en el desproporcional impacto ambiental, la vida en decadencia, el oro en afluencia que convoca una multitud flotante, ansiosa de escarbar por su dorado; sueños tan efímeros como la opulencia que configura un entorno ruidoso y desgarrado, rebosante de escombros, donde el agua limpia es una utopía, las condiciones de vida son precarias, y el costo de vida altísimo; empezando por las drogas, hasta el agua, la energía, las chozas restaurante, la prostitución, los socavones, plantas de beneficio "entables", compraventas de oro, herramientas y todo lo relacionado con las minas de beta en la región; los explosivos, el mercurio y la ley son administrados por grupos paramilitares muy bien dotados de arsenal militar y ningún sentido de la piedad; pero si uno muy propio y particular de la justicia, quienes realmente gobiernan esta multitud flotante que circula en los socavones y los entables a donde llegan personas de todos los lugares, incluso quienes nunca tuvieron nada que ver con la minería, aquí resultaron ansiosos de riqueza; que destelló en todos los municipios circundantes a donde fueron a "catear" y efectivamente, se mostró el oro con un resplandor de violencia y excavaciones que se extienden desde Santa Fé de Antioquia, a donde también llevan el material desde Buriticá, las minas más grandes (El Hebrón y Los Costeños) que

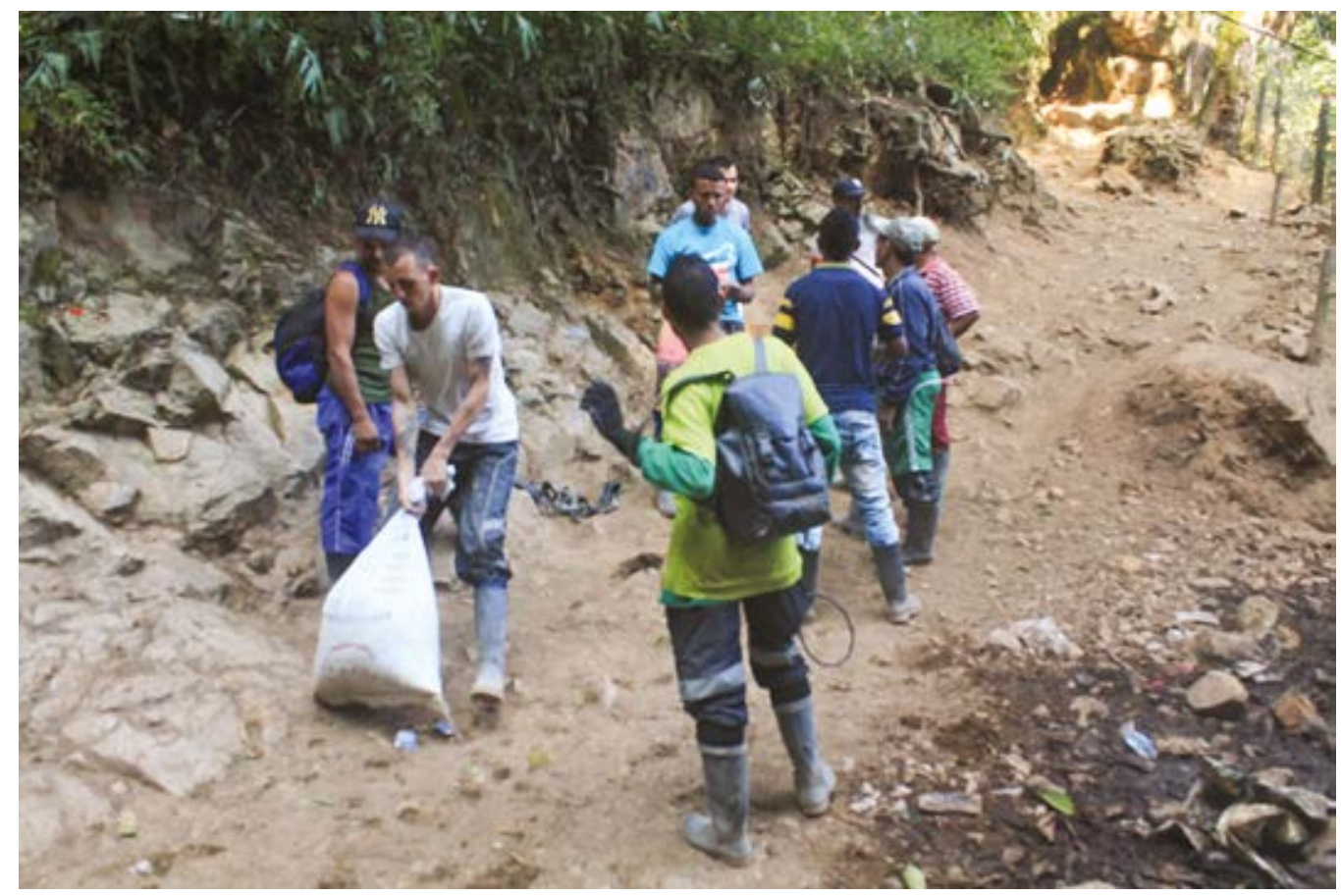

Imagen 3. Expectativas de la "Góngora", rumbo al cateo. Daniel Ospina Moreno (2016). 


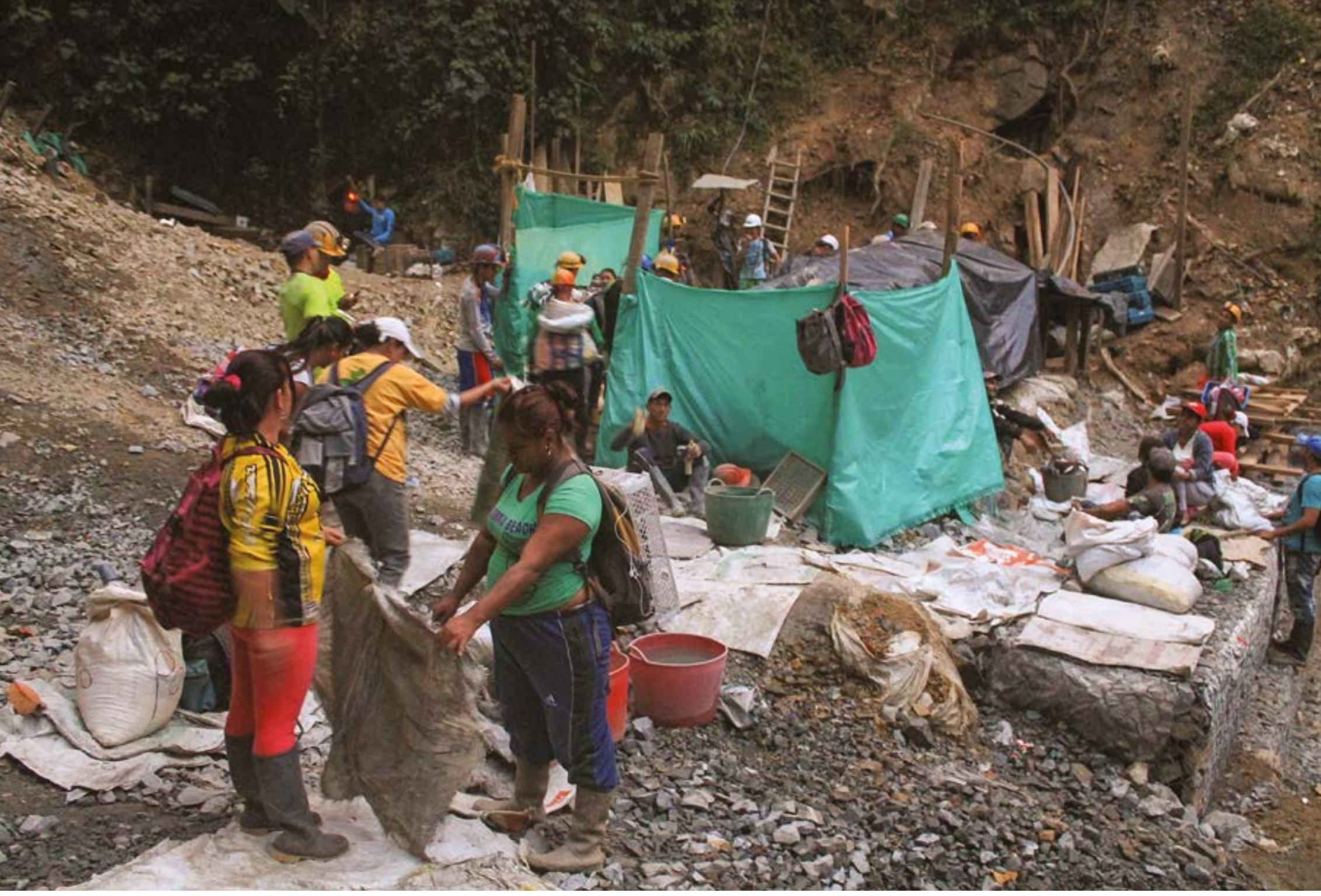

Imagen 5. Chatarreros... son quienes observan cada roca y decantan el descargue buscando el orito que se escapó de la mina... Daniel Ospina Moreno (2016). 
tienen sus entables a unos 50 kilómetros del socavón por la Vía Marginal del Cauca, hay socavones por Cativo, Pingúro, el mismo Buriticá, origen de la enfermedad en la región, que llega a Giraldo y desde allí por el Tonúsco y por el boquerón del Toyo, desciende a Cañas Gordas, Uramita, Frontino, Dabeiba.

Así mismo, se extiende esa huella que transforma desde el tejido social hasta el natural, un fenómeno donde participan muchas personas, pero realmente se enriquecen muy pocos, y surge la pregunta ¿A dónde va todo ese oro? ¿Quién está en capacidad de comprarlo? ¿Si la producción de oro de Colombia no se queda en Colombia será que los billetes y los lingotes tienen orígenes y rumbos diferentes? El caso es que esos billetes se van muy rápido de los bolsillos de quienes desollan la montaña, sepultan y envenenan sus aguas para conseguir el metal ¿Cómo es su vida? ¿Cómo es su entorno? Esta narración pretende llevar de viaje al lector por ese paisaje desgarrado que concibo desde la metáfora del Sísifo que personifican muchos de los seres que habitan en torno a estas minas, en retorno eterno desde las profundidades del subsuelo, con las entrañas de la montaña a las espaldas, anestesiadas de espejismos dorados, seres que habitan la noche perpetua del socavón conscientemente indiferentes de su entorno desgarrado, todo lo justifica el metal dorado, que vale más que la dignidad, la lealtad, la honestidad, la amistad, el amor e incluso la misma familia, más que el agua, la naturaleza y la vida, aquí el metal está por encima del bien y del mal es el propósito y el fin de la vida... escarbar.

Ante la difícil geografía... Ancestral tracción animal... las mulas que ayer cargaron café... Hoy mina.

\section{3 horas da vueltas en el "coco" con la arena y esferas} de hierro que la hacen finísima como crema...

Hablo del legendario Prímido, pues allí todos conocen la historia de este personaje que recién llegó se asoció con alguien para invertir en una operación minera, cuando esta dio fruto, cada bulto llegaba a producir una libra de oro, a pesar de ser mucho el no quiso compartir con su socio y lo mando asesinar... esta historia se ha repetido muchas veces entre los mineros... en el

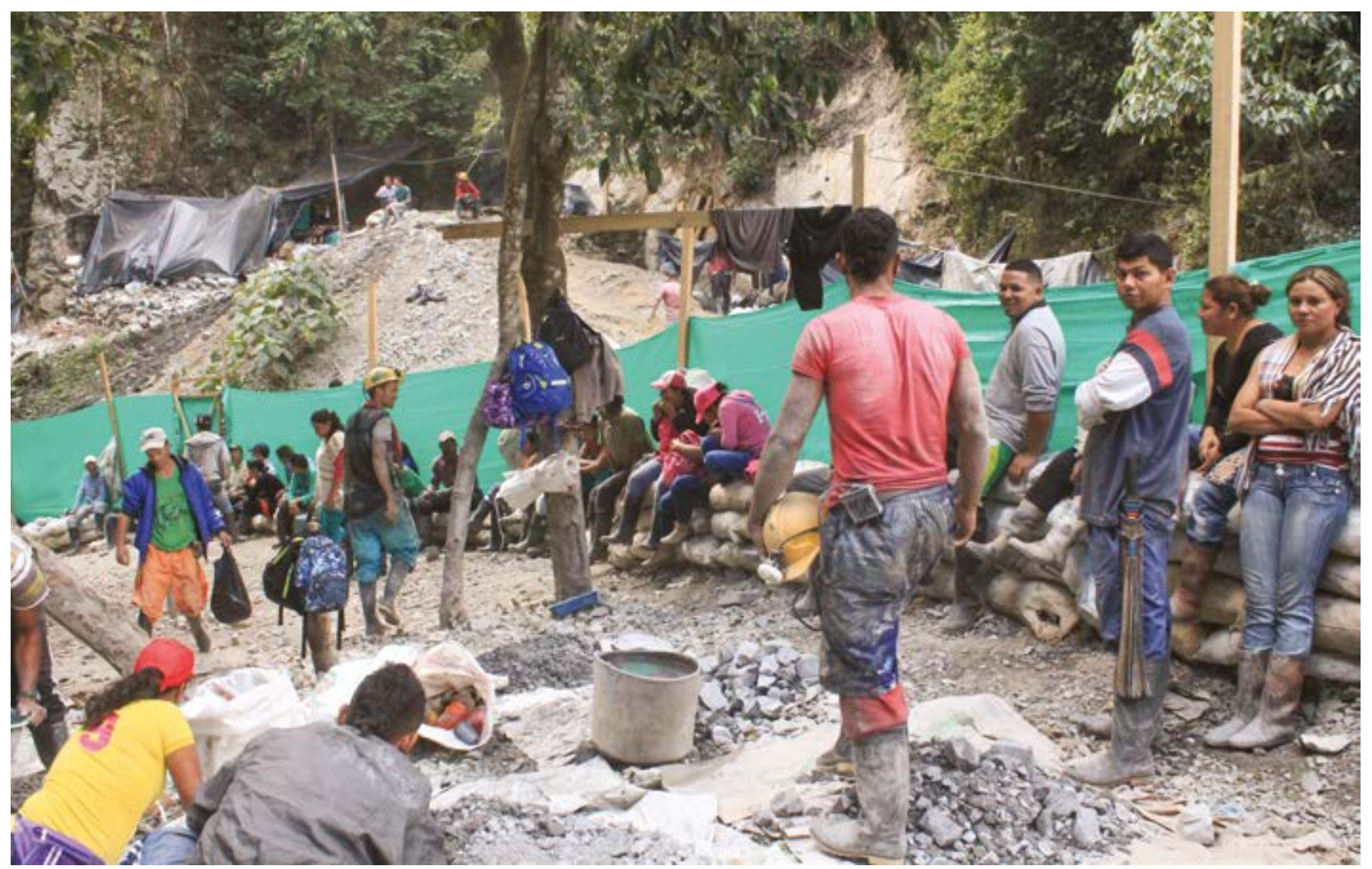

Imagen 6. Fila para el descargue... Chatarreros... Daniel Ospina Moreno (2016). 
entable de Prímido es tanto el oro que el mercurio no tomó de la arena a la que no se le pudo tomar todo el mercurio que con ella se mezcló ni todo el oro que en ella habita... que estas arenas "relavadas" viajan dos veces a la semana y a pesar de los cuantiosos gastos en mulas para sacarlas del entable considerando que se cargan entre uno y tres camiones rumbo a Segovia y por cada camión doble troque que lleva estas arenas a su encuentro con el cianuro se pueden lograr ganancias alrededor de 20 millones de pesos para el 2016... mientras más me adentro más incomprensible se me hace, que el precio de un metal pueda suplir tanta logística, gasto energético sin contar con la degradación ambiental y social... irreparable.

Contemplo un panorama montañoso, que revela sus heridas y su contaminación a medida que me acerco, en principio no logro comprender la constante barrera visual que generan las telas verdes que se suelen usar para cercar las obras en construcción, el cerramiento casi total que solo deja abiertos la carretera y algunos caminos de herradura que conectan esta red de cerramientos que parece una gran construcción, pues hay escombros por todos lados y estas telas verdes, que encubren y resguardan socavones y plantas de beneficio "entables", es bastante complejo pasar al otro lado de estas telas, mallas, rejas; la extrañeza se nota en los rostros, la curiosidad, a pesar de la desconfianza que nunca se vence, la incertidumbre que entre todos existe y más con un sujeto como el que escribe estas palabras, poco convencional para el contexto. Sin embargo, se logró generar diálogos empáticos y podría decir que me sentí acogido, protegido y ayudado, bastante aconsejado sobre el cómo ingresar. Después de mucho cuestionarme, se mantiene la advertencia al comprobar que, efectivamente, "estamos en las mismas" cuidado con el ioro!, el dinero, las cosas personales "ande con lo suyo siempre". Cuando me acerco más se nota la escasez de agua y su sobrecarga de sedimento, que va desde la más fina arena de los entables hasta las toneladas de roca pobre que hay que sacar del socavón para "avanzar", por eso la acumulación de la "chatarra" o el "descargue" lo asocio al fenómeno de la colmatación que es precisamente lo que sufre el río Atrato al otro lado de la cordillera occidental donde

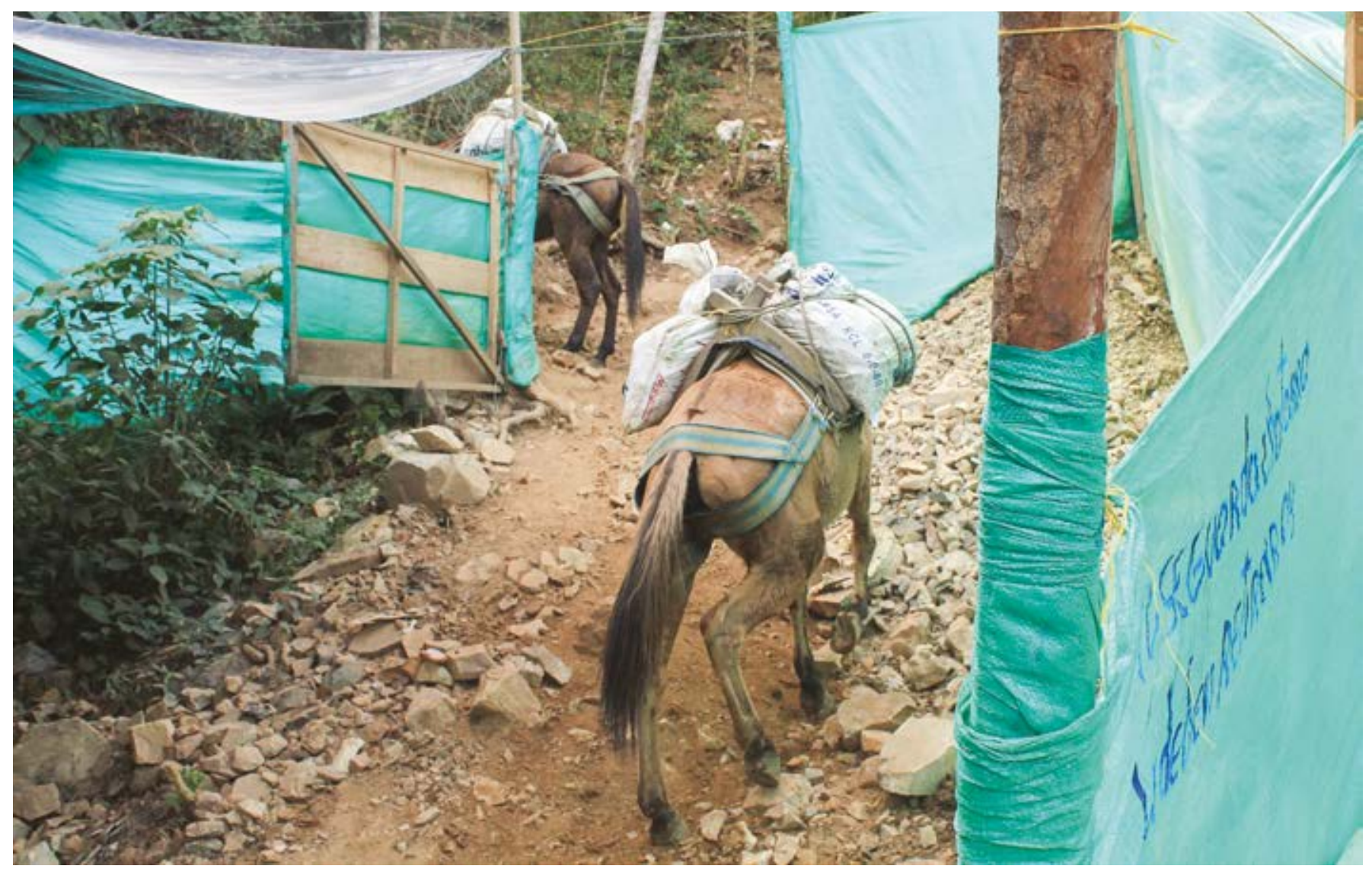

Imagen 7. Mulas... Daniel Ospina Moreno (2016). 


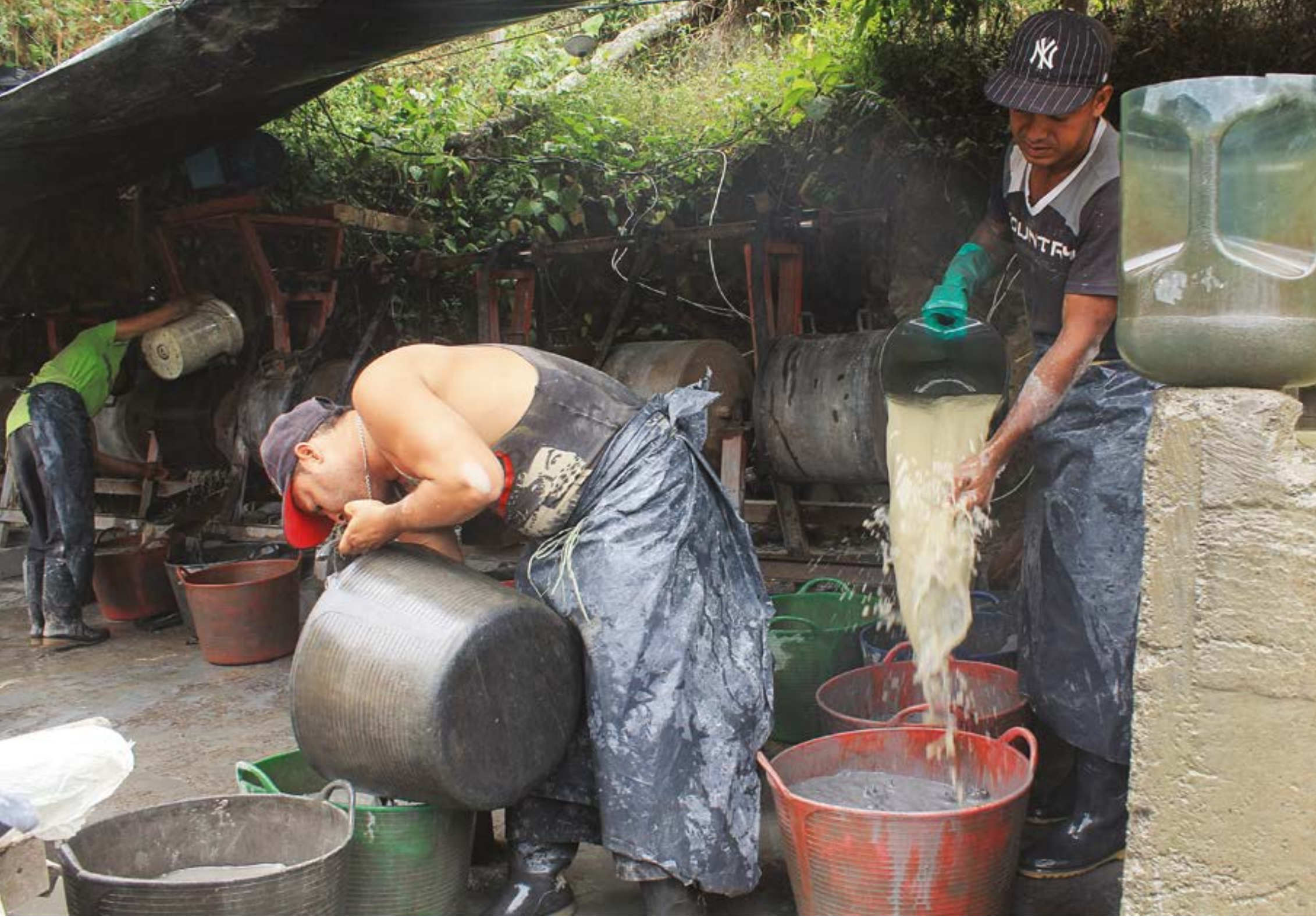

Imagen 9. Lavar y relavar la arena "nunca se coge todo el orito..." Daniel Ospina Moreno (2016). 
se encuentra Buriticá; la colmatación ha restado más de la mitad de la navegabilidad del río a causa de la sobrecarga de sedimentos en su cauce, en este caso ni vemos el agua que corre entre los sedimentos por los que camina la fatiga que los llevó allí...

Este es el punto inicial de la actividad minera alterna a la multinacional Continental Gold, de lo que afirman, los ilegales apenas se comen las cuñas de lo que ya se comió la empresa multinacional, en términos locales que también se emplean en la geología una "cuña" como su nombre lo indica es una ramificación, una extremidad de una formación mineral más amplia; hay quienes se hacen ricos de estas cuñas. Por lo que los mineros suelen decir "!cómo es posible que la riqueza de nosotros se la lleven los gringos!" este es el principio de la experiencia, aquí conocí mis primeros mentores, "El Barbas", entre ellos un amigo de Pereira. Por Aquí ingresé por primera vez a lo que a primera vista me dije:"si existe el infierno se debe parecer a esto...", "La Cañada".

Alrededor de las operaciones mineras, se mantienen vestigios de esos días agrarios...

Aún hay alimentos sembrados y cualquier recipiente es una maceta, el establo se volvió entable...

Vemos la pequeña cavidad por donde entran y salen hombres cargados... ¿Cómo respiran? Es esa la razón del motor y el tubo que apreciamos entrando por un costado del agujero, al que llaman Búfalo, vital también para remover los gases tóxicos de la dinamita y el anfo, al que llaman "pique", las cargas explosivas se detonan en el cambio de turno de las minas ya que estas trabajan 24 horas y las mechas deben ser lo suficientemente largas como para que los mineros alcancen la superficie, pues luego de la detonación muy rápidamente se esparcen los gases cayendo dormidos antes de ver la luz del exterior, aunque es cotidiano que un desprendimiento de rocas al interior de un socavón sepulte a uno, dos o todo el turno... aquí que la tierra se trague la gente no es tan remoto... de hecho a diario nos dirigimos a sus entrañas...

El Frentero perfora la roca, ubica y detona los explosivos selecciona el material (mina-descargue).
"La catanga" es una práctica ancestral, de la etnia Katío y se emplea desde la colonia, esta consiste en hacer uso de canastos donde se cargaban cosechas $u$ otros productos para intercambiar, consiste en llevar un canasto que se sujeta de una única cargadera que se cuelga en la cabeza y se hace soporte con la espalda; para los mineros este elemento ha cambiado a un sostén de riatas de donde salen dos cargaderas, que hacen que el bulto de roca se pueda llevar en la espalda con las manos libres para sortear las dificultades que implica desplazarse por el socavón donde hay que agacharse, agarrarse de las rocas, caminar en pendientes así como en verticales por escaleras.

Lo que lleva el minero, que ocupa el punto central en la imagen, es a lo que llaman "catanga" solo que este lleva apenas el costal enrollado que al fondo del socavón se llenará de entrañas de montaña, unos 90 kilos que saldrán a la superficie en la espalda de este hombre. Qué busca el sol en la oscuridad del vientre de la tierra, triturarse hasta su mínima expresión y mezclarse con metales pesados y químicos tóxicos hasta su máxima expresión para luego fluir y diseminarse con el agua y como el agua, sin ninguna contención ni precaución, solo por la acción de la gravedad que obliga su escorrentía.

El cuerpo a cada día se nota más desgastado y agotado de cargar estos pesados bultos del piedras... En palabras de los segovianos "el catanguero se gasta rápido" rodillas... espalda... sangre con mercurio, excesos...

Aunque el mismo entorno ya es abrumador, lo más difícil de habitar este lugar es la gran imposibilidad de conseguir agua pura y potable o así sea un riachuelo para bañarse, aquí es una posibilidad remota y el único abasto de agua potable y sitio de baño es un pequeño tanque de donde sale un diminuto chorro de agua, que es el abasto de muchísimas personas; por lo que en el mundo de los Sísifos todo es irrisorio empezando por que prefieren el oro al agua, aunque sin agua no se pueda sacar oro, por eso toda está contaminada y gris... 


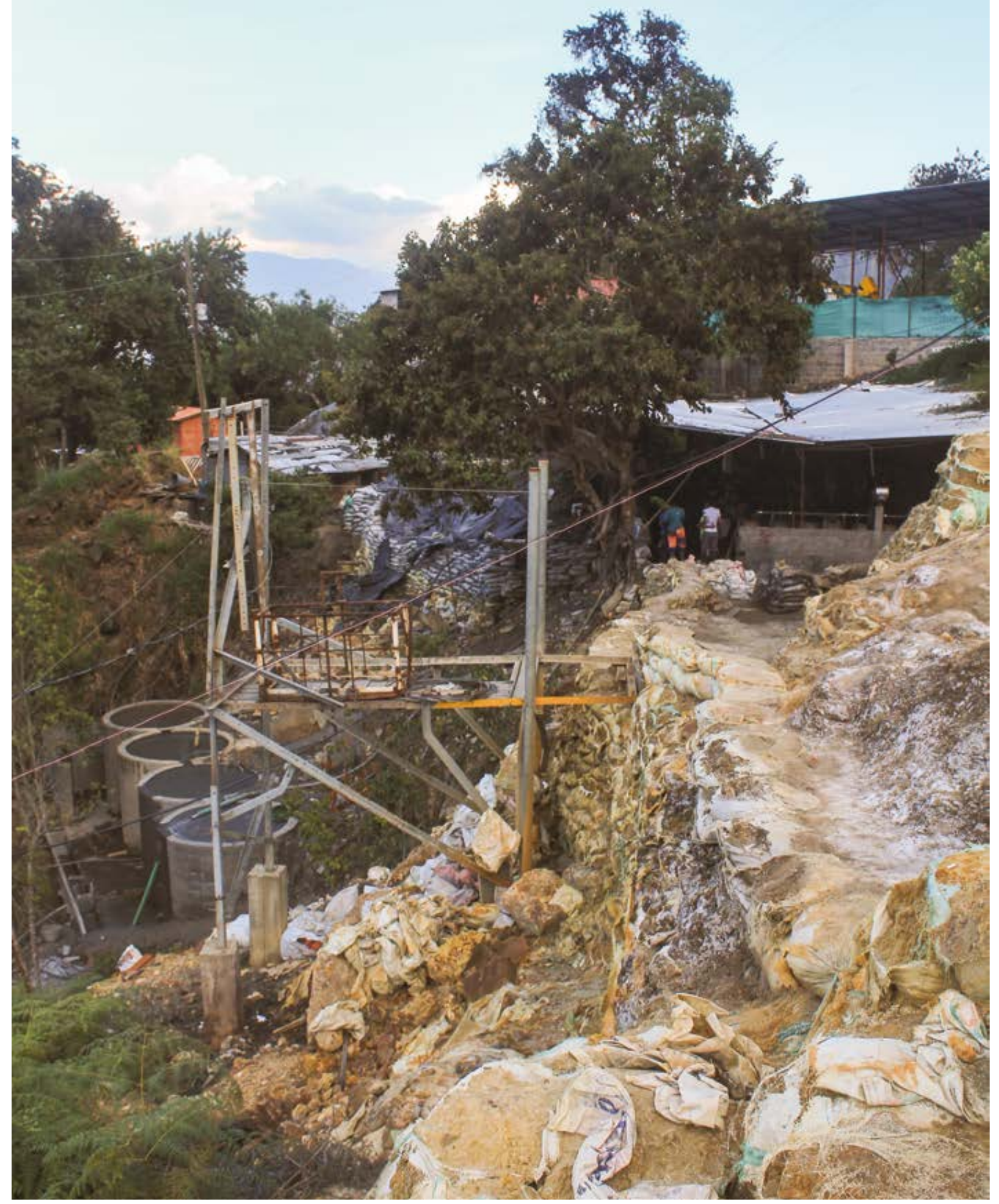

Imagen 10. El gran Entable del legendario "Prímido" uno de los primeros segovianos que por acá vino a probar suerte... Daniel Ospina Moreno (2016). 


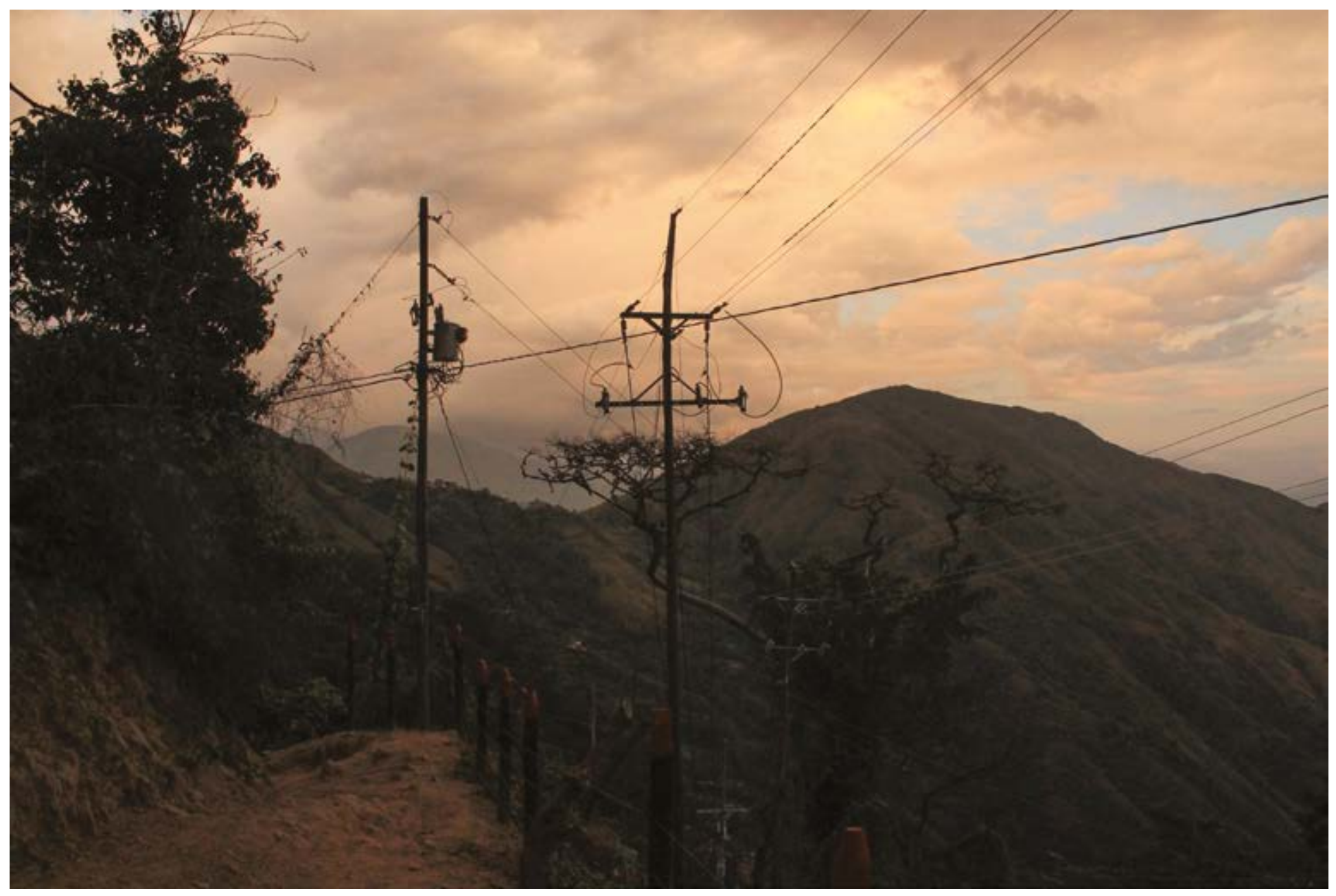

Imagen 12. Camino de herradura y San Antonio patrono de los mineros y cerro tutelar de Buriticá... Daniel Ospina Moreno (2016). 


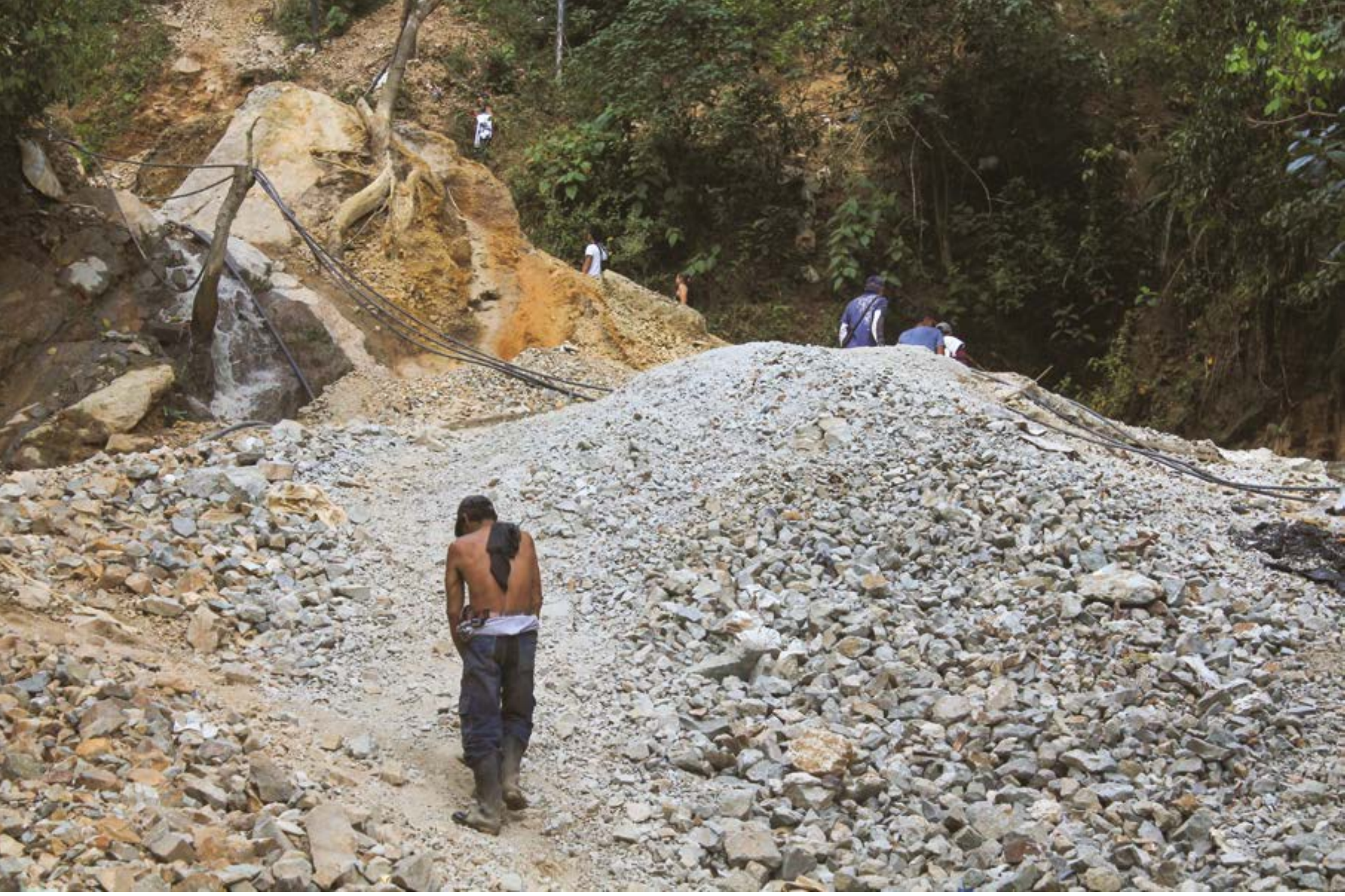

Imagen 13. Fatiga y comaltación. Daniel Ospina Moreno (2016). 


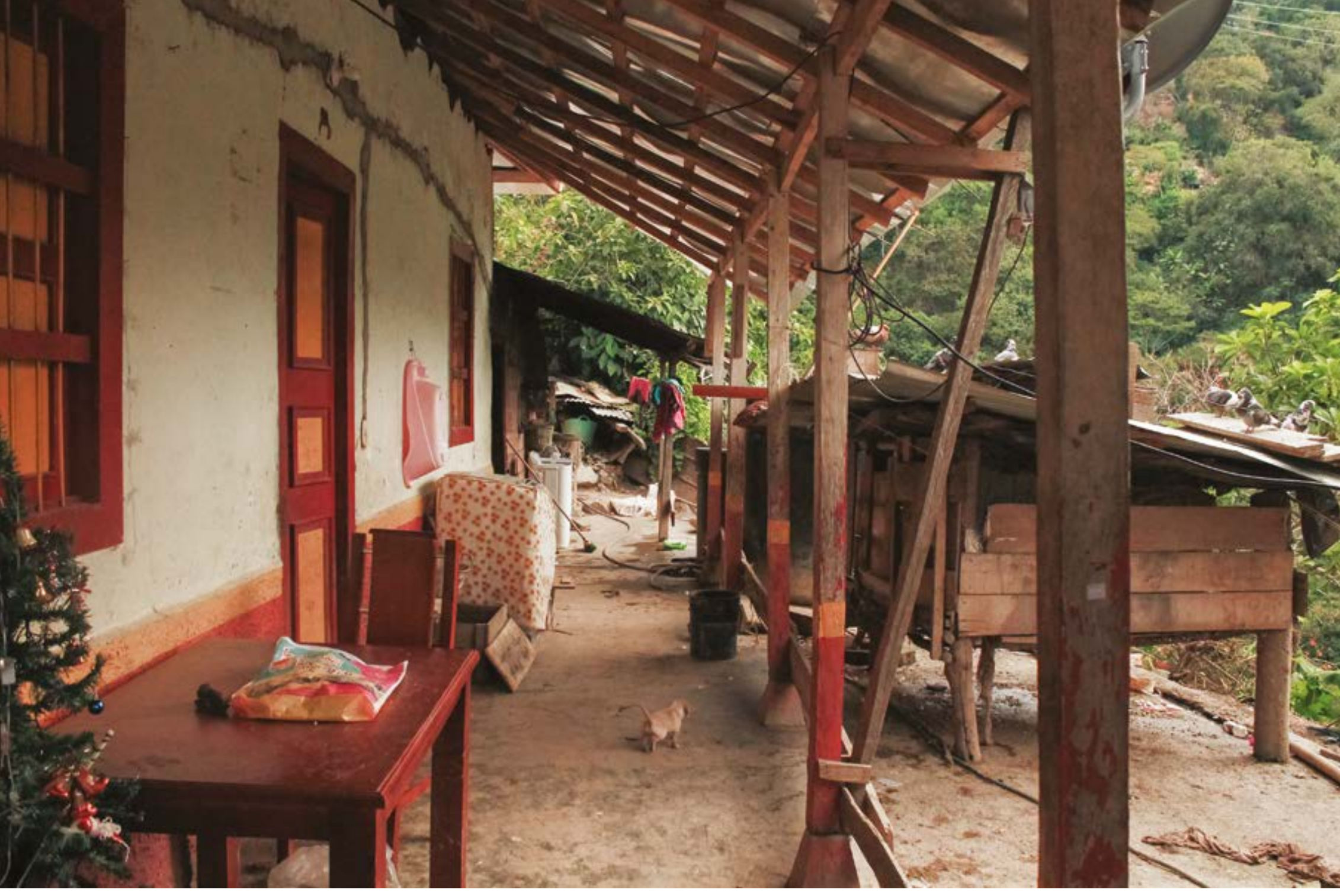

Imagen 16. Entrando al entable de "La Abuela". Daniel Ospina Moreno (2016). 


\section{Referencias}

Camus, A. (2015). El mito de Sísifo. Madrid: Alianza Editorial.

Cárdenas, H. S. (9 de marzo del 2016). En Buriticá capturan al exsecretario de Gobierno, tres policías y 11 personas más por minería ilegal. El Colombiano.

Isaza, G. M. (9 de diciembre de 2015). Alcalde de Buriticá, capturado por nexos con Urabeños. El Colombiano.

Martínez, A. R. (19 de enero de 2016). Hoy inician el desalojo de 13 minas en Buriticá. El Colombiano.

Matta, C. N. (7 de junio de 2015). Lío en Buriticá por estudio de uso del suelo que pagó multinacional. El Colombiano.

Ospina, M. D. (2017). Destierro, una revisión poética del diálogo contemporáneo hombre-naturaleza en el Chocó colombiano. Revista Colombiana de Pensamiento Estético e Historia del Arte, 5 (enero - junio), pp. 149-190.

Proyecto Buriticá. [En línea] oficial Continental Gold, http://www.continentalgold.com/es/proyectos/buritica/

Rendón, L.E. (11 de junio de 2016). El cura de la minería ilegal en Buriticá. Revista Semana. Recuperado de https://www.periodismoinvestigativo.com.co/2016/ 06/12/el-cura-de-la-mineria-ilegal-en-buritica/
Revista Semana. (14 de mayo de 2016). La maldición de Buriticá. Recuperado de https://www.semana.com/ nacion/articulo/buritica-gobierno-busca-quitarle-minade-oro-a-urabenos/473506

Revista Semana. (26 de abril de 2014). La tragedia que enluta a los habitantes de Buriticá. Recuperado de https://www.semana.com/nacion/articulo/ explosion-en-mina-en-antioquia/384862-3

Revista Semana. (29 de junio de 2016). Ellos se creen los dueños del mundo. Recuperado de https://www. semana.com/deportes/articulo/se-confirmaron-lasfechas-de-la-final-de-la-copa-libertadores-sera-rivervs-boca/589154

Revista Semana. (31 de enero de 2015).

El drama del oro colombiano. Recuperado de https://www.semana.com/economia/articulo/ mineria-el-drama-del-oro-colombiano/416246-3

Rosier, D. (productor). Wenders, W., y Ribeireo, S. J. (directores). (2014). La sal de la Tierra [documental]. Alemania, Brasil: Decia Films.

Valencia, L. (30 de abril de 2016). Buriticá, punta del iceberg de un gran problema nacional. Revista Semana. Recuperado de https://www.semana.com/opinion/ articulo/leon-valencia-buritica-y-el-conflicto-de-lamineria-ilegal/471543 


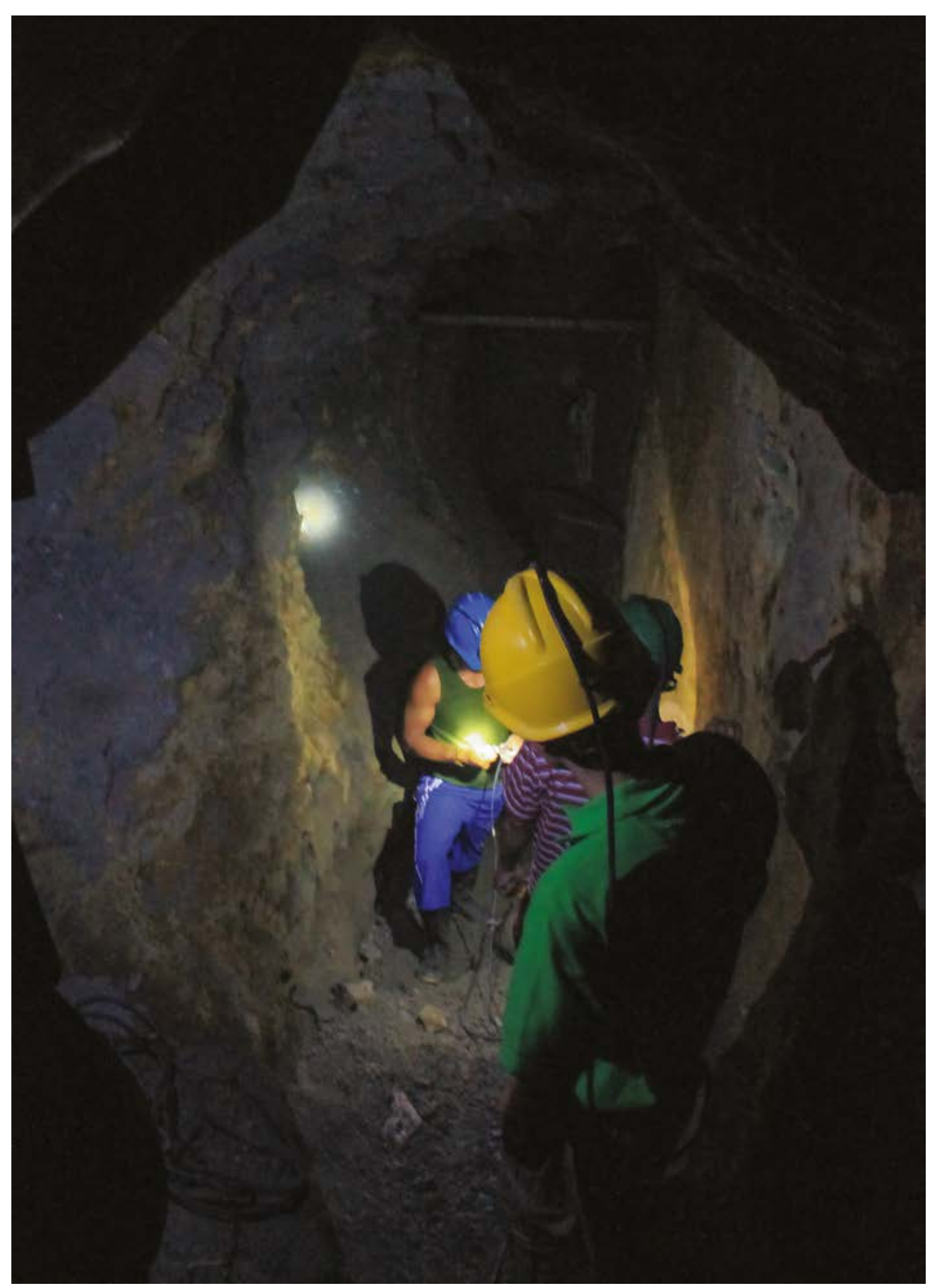

Imagen 17. Mina "la Roca". Daniel Ospina Moreno (2016). 